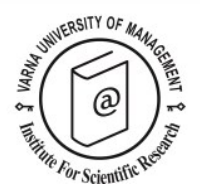

\title{
An insight into cultural heritage management of tourism destinations
}

\author{
Fabio Carbone $e^{1,2,3 *}$
}

Received: 09/04/2015 Accepted: 07/02/2016

\footnotetext{
1 Faculty of Business and Law - School of Marketing and Management, Coventry University, UK

2 Research Unit "GOVCOPP - Governance, Competitiveness and Public Policies", University of Aveiro, Portugal; email: fabiocarbone.pro@gmail.com

3 "CGEO - Geosciences Center", University of Coimbra, Portugal

*

Corresponding author
}

\begin{abstract}
In this time of global changes, culture is considered the fourth pillar of sustainability, and intercultural dialogue and understanding is an increasingly important issue. Within this context, the preservation, management and cultural heritage enhancement is more than ever at the centre of international debates, as well as its alliance with tourism. Supranational guidelines address the effort of policymakers and operators, but how to guarantee the effective implementation of supranational guidelines at local level and for each monument and cultural area open to the public? In this context, Cultural Heritage Quality Management is an emerging topic, and this article aims to provide a milestone in its study by offering a detailed theoretical overview as a starting point for future empirical research in this area.
\end{abstract}

(C) 2016 Varna University of Management. All rights reserved

Keywords: Cultural Heritage; Cultural Heritage Quality Management; Tourism; Sustainable Development.

Citation: Carbone F. (2016) An insight into cultural heritage management of tourism destinations. European Journal of Tourism Research 14, pp. 75-91

\section{Introduction}

Complexity characterizes today the ontological and epistemological approach to the study of the phenomena that surround us. The present work embrace this paradigm and aims to look at the management of cultural heritage and its link to tourism development considering the complexity of the implication in several areas, at local, regional, national and international level. In this time of global changes in terms of economic paradigms, geopolitical stability and international security, culture is considered the fourth pillar of sustainability. Cultural heritage becomes the central topic of many debates. It is included in the considerations regarding local development from the economic point of view (Mazzanti, 2003; UNESCO, 2000), as well as the debates about heritage awareness (Oosterbeek \& Pollice, 2014). Still, cultural heritage and its management is nowadays a 
central point within the debates on integration and intercultural dialogue (Carbone, Oosterbeek, \& Costa, 2012) and multicultural societies (Colombo, 2011). Culture and cultural heritage become vital within the process of tourism destinations development, attractiveness and their competitiveness (Boniface, 1995; Malek \& Costa, 2014; McKercher \& du Cross, 2002).

In a broader sense, we need to contextualize the implication of cultural heritage management within the post-capitalist society in which we live. According to authors such as Drucker (2015) or Bounfour and Edvinsson (2005), among others, in the post-capitalist society the knowledge represents the primary resource for development. On the other hand, the New International Setting is based on full economic and international integration and, at the same time, on the enhancement of diversity, thus on the self-knowledge. The latter is provided at several levels as a result of a process in which the role of culture and cultural heritage management is crucial. Culture is indeed evocated as an essential resource within the new paradigms of international relations and "soft power", and the cultural diplomacy is seriously taken in consideration by the most prominent nations (Gienow-Hecht \& Donfried, 2010; Mazzei, 2012: 35).
In this context, the holistic approach leads us even further into D'Amore (1988)reflection about tourism as a great vehicle of peace and mutual understanding among different communities, through its capacity of putting people with different cultural background (visitors and host community) in contact with each other. In order to reach this goal, however, coherent, new and integrated policies and approaches to cultural heritage management for the integration between tourists and local communities should be developed. In this perspective, for instance, even the director of a small museum contributes not only to the local community development, but also to a global process of sustainable development and intercultural dialogue. The notion of supranational and cross border cooperation through tourism is a concept also approached by Timothy and Saarinen (2013).

One thus understands the multiple implications of a reflexion on cultural heritage quality management of tourism sites. The contribution of the present work is therefore to provide a theoretical framework to meet the point of convergence of these three areas - cultural heritage management, tourism and development. Below we present Figure 1 to illustrate schematically the reasoning developed based on the literature review along the sections of this article.

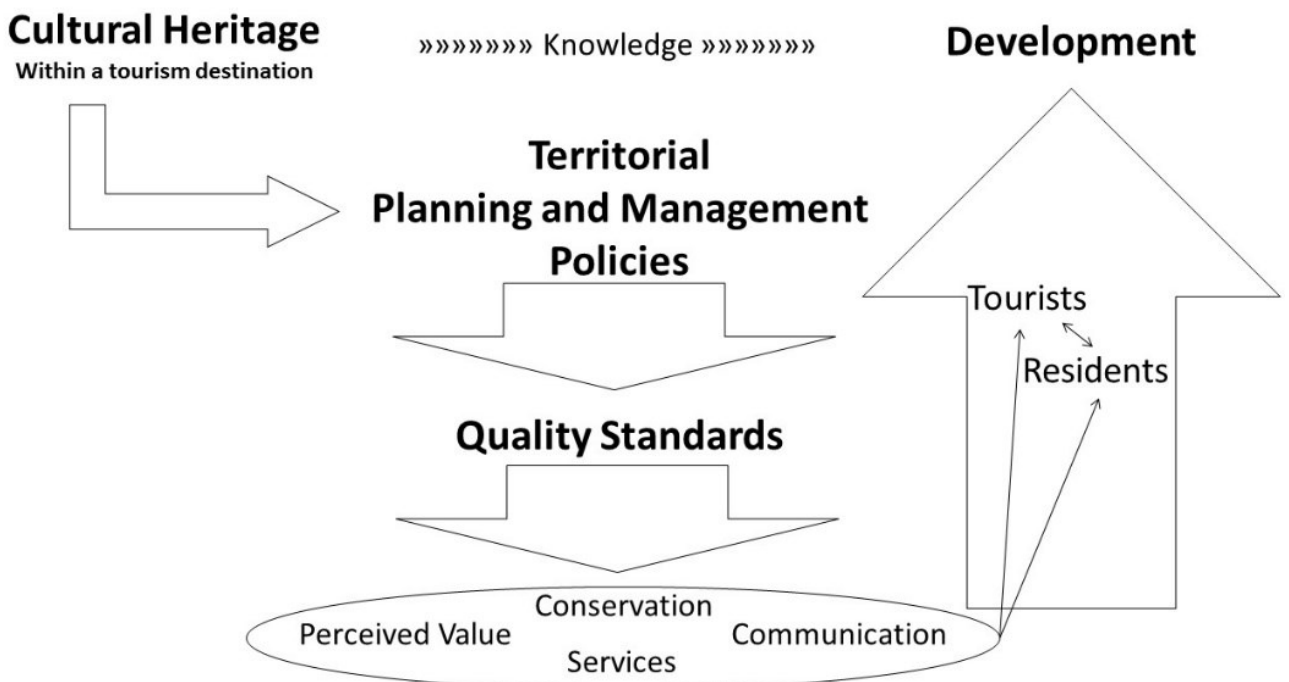

Figure 1.Proposed Theoretical Approach to the analysis of the Cultural Heritage Quality Management within Tourism Sites

Source: The author 
Having assumed that the cultural heritage and its knowledge is one of the elements that can drive towards the socio-economic and cultural development, its management should be based on territorial planning and management policies clearly aiming at the cultural heritage enhancement within the process of local development (Sections 2 to 4). Such a policy, together with the management practices implemented, require parameters to standardize the quality of each effort (Section 5). As Spyriaris, Fletcher, and Fyall (2013) have already noticed, despite the existence of over one hundred public or private certification labels, the utilisation of quality management systems in Destination Management Organisations (DMOs) is still the exception rather than the rule. Some of these labels are examined in Section 6. On the other hand, up to the date, the only system promoting internationally accepted dimensions in this field of cultural heritage management is the HERITY Global Evaluation System, officially recognized by UNESCO and the World Tourism Organization (UNWTO). These dimensions (applicable to the analysis of the management practices of every and each monument, archaeological area, etc.) are the perceived value of the monument by the visitors, the capacity of conservation, the ability to communicate the intrinsic meaning of the cultural heritage as well as its importance and, finally, the services associated with the monument so that the visitor experience could be considered pleasant (Section 7). Recipient of this effort are the tourists, of course, but also the residents themselves. Further effort, as we shall see in the conclusion (Section 8), would be to make sure that the quality is also concern with the ability to stimulate dialogue (and intercultural dialogue) between residents and tourists, on the basis of the promotion of cultural heritage. This and other proposals represent the starting point for future insights and researches, asserting the need for this new line of research in Cultural Heritage Quality Management.

\section{Cultural Heritage: "resource" or "tourist attraction"? Conceptual analysis}

In order to analyse the topic of cultural heritage management within tourism development it is essential to understand the conceptual difference between resource and attraction, that is, which are the necessary elements for enhancing the cultural heritage to make it accessible to the public. We indeed assume that cultural heritage in itself does not represent a tourist attraction, but a resource of the territory with the inherent potential to become a tourist attraction (Pearce, 1991). This idea is brilliantly exposed by Gunn (2002: 41-42) when he affirms: attractions are those developed locations that are planned and managed for visitors interest activity and enjoyment. Even though a destination may have an abundance of resources that are attractors, they are not functioning as true attractions until they are ready to receive visitors. Theoretical clarification aims not only to lay the foundation for the discussion of cultural heritage management models, but also to raise a certain awareness about this distinction - between cultural resource and cultural tourist attraction. From a sectorial perspective in fact, it represents an essential base of knowledge for policy makers and all those stakeholders who are dedicated to heritage management and tourism development. In other words, we are firmly convinced that this awareness in itself represents a valuable resource for the success and competitiveness of a destination. In fact, even if attractions represent a key element in the development of tourism destinations, they have been traditionally neglected in the tourism industry on behalf of sectors like hotel trade, transport and travel agencies (Cooper, Fletcher, Gilbert, Sheperd, \& Wanhill, 1998: 140).

MacCannell (1976) has provided one of the first conceptualizations about the components of a tourist attraction: the interaction of three elements define the tourist attraction (differentiating it from the concept of "cultural resource"):

1) A tourist;

2) A place to be seen and

3) A "marker", that is, something that provides information on the site.

Traditionally, Gunn (1988: 49) describes an attraction as a system of three concentric rings, where the ring in the middle represents the "nucleus" (the resource itself); the second ring represents the "inviolate belt" or "region" (the area surrounding the resource); and finally the 
third ring, "zone of closure" (all the secondary tourist resources, infrastructure and services supporting the tourist activity). Later, Leiper (1990: 370) considered a tourist attraction as a system of three elements: the human element (the tourist, a person with touristic needs); a sight (meaning, the feature to visit, the "nucleus" of the system) and at least one "marker", or "informative element" (information about the nucleus). It should be noted that Leiper (1990) emphasizes that an attraction only exists where these three elements interact. Pearce (1991) focuses on the characteristics that determine the success of tourist attractions. Briefly, he theorizes that a tourist attraction will be successful if:

1) Visitors have a clear perception of the resource presented on the site;

2) The activities offered are clearly understood;

3) The physical attributes are varied and aesthetically pleasing.

Today, academics are creating new perspectives to analyse the process of tourism product development (Malek \& Mohamed, 2014) and the phenomena that affect the relationship between cultural heritage and the process of transformation into a tourist attraction (Richards \& Munsters, 2010). Some authors focus on the relation between sustainability and competitiveness in destinations development (Moraes, 2006), while others focus their attention on the modality of involvement of the local community (Malek \& Costa, 2014), as well as on the centrality of culture in tourism experience, by proposing a shift from the traditional paradigm of the 3-S Tourism (Sun, Sand and Sea) to the paradigm of the 3-L Tourism: Leisure, Landscape and Learning (Carbone, Oosterbeek, \& Costa, 2013: 288).

In summary, the empirical evidence and theoretical knowledge demonstrate the necessity of subjecting the cultural resource to a process of enhancement that makes it attractive, accessible and intelligible to the public. A process that turn the cultural resource in cultural attraction, promoting cultural heritage as a distinctive element in the construction of destination branding.
Considerations on the relationship between cultural heritage and competitiveness

Tourism development is usually embraced as an opportunity for socio-economic development, but the emergence of new destinations pushes to strengthen the capacity of attracting tourists through a high level of competitiveness. The latter is given, on the one hand, by the ability to meet the visitor needs and provide a satisfactory experience which motivates him to come back (and recommend) the visited destination (Alegre \& Garau, 2010); on the other hand, by the ability to enhance the "personality" of the destination (Ekinci \& Hosany, 2006) through an increased promotion of cultural heritage, which in most cases is the real differentiating factor of the tourist experience.

On the demand side, the intensification of competitiveness among destinations is related to the increasing number of more informed, selective and exigent tourists. Once again, not only the quality of the services must be improved for a satisfactory positioning of the tourist destination, but also the differentiation through the enhancement of cultural, tangible and intangible heritage, which unequivocally confers uniqueness to a territory (Ekinci \& Hosany, 2006). In this context, studies examine how expectations, experiences, and satisfaction are related in the context of cultural tourism and the services provided by cultural organizations (de Rojas \& Camarero, 2008). International and domestic travels are increasingly motivated by the will to experience cultural heritage, which has become the essence of tourism in many tourist destinations worldwide (Dallen, 1996). Finally, it is possible to affirm that the increased demand for cultural experiences and the mobilisation of cultural heritage to attract tourists (Bowitz \& Ibenholt, 2009) has made cultural heritage one of the most powerful factors of competitiveness for tourist destinations. The management and enhancement of cultural heritage as tourist attraction assumes, thus, a strategic importance for destinations.

\section{The process of internationalization of responsibilities regarding the protection and management of cultural heritage}

Cultural heritage management can be described, nowadays, as a "global practice" 
oriented by a series of internationally recognized codes and charters which takes systematic care "to maintain the cultural values of cultural heritage assets for enjoyment of present and future generations" (McKercher \& du Cross, 2002, p. 43). It is possible to recognize also an increasing value of cultural heritage, both tangible and intangible, in contemporary political discourse, although this appreciation is crossed by a fundamental contradiction between its ideological program, globalized and convergent, and its legal constraints given by the national level of performance (Oosterbeek, 2015). Until the end of the 19th century, in fact, architectural heritage had been a matter of national concern only and most of the laws regarding the protection of historic buildings in Europe date back to that period. Countless association existed in each country, but their scope never went beyond national borders.

Cultural internationalism, as we know it today, was an outcome of the First World War, with the creation of the League of Nations - trying to assure a sense of international stability (Archer, 2001: 14; Bell, 2007; Kawamura, 2000: 135) and even more of the Second World War, when - as response to the tragic events of the war the United Nations Organisation was created and later the United Nations Educational, Scientific and Cultural Organization (UNESCO), was established with the main purpose to promote peace through science, education and culture. In 1957, in Paris, the First Congress of Architects and Specialists of Historic Buildings recommended that the countries which still lack a central organisation for the protection of historic buildings provide for the establishment of such an authority and, in the name of UNESCO, that all member states of UNESCO join the International Centre for the Study of the Preservation and Restoration of Cultural Property (ICCROM) based in Rome. Based on the new paradigm of internationalization and sharing of the awareness about the preservation of heritage, the Second Congress of Architects and Specialists of Historic Buildings, held in Venice in 1964, has produced the International Restoration Charter, better known as Venice Charter (ICOMOS, 1964). The document contained in itself the summary of all the small but crucial changes in the last thirty years in the paradigm of cultural heritage management, stating it is essential that the principles guiding the preservation and restoration of ancient buildings should be agreed and be laid down on an international basis, with each country being responsible for applying the plan within the framework of its own traditions and cultures (ICOMOS, 1964, p. 1).

At the same time, it is clear that the concrete actions of preservation and conservation become exclusive responsibility of different countries, also in respect of the culture and modus operandi of each. It is important to notice that, as stated in Article 1 of Venice Charter (ICOMOS, 1964: 1), the concept of historic monument embraces not only the single architectural work but also the urban or rural setting in which the evidence of a particular civilization, a significant development or historic event is found. And it continues by stating that this applies not only to great works of art but also to more modest works of the past which have acquired cultural significance with the passing time.

In the Second Congress of Architects and Specialists of Historic Buildings, it was created the International Council on Monuments and Sites (ICOMOS), an international nongovernmental organisation for the conservation and protection of cultural heritage places. It also promotes the application of theory, methodology, and scientific techniques to the conservation of the architectural and archaeological heritage, on the basis of the principles enshrined in the Venice Charter. More specifically with regard to the archaeological heritage and its management, ICOMOS has at its disposal a specific committee on matters that pertain to all aspects of the management of archaeological sites and landscapes. These include formulating and propagating standards and best practices for both archaeological research and cultural resource management. Since then, ICOMOS and UNESCO have drawn more and more specific documents that represent the evolution of the concept and scope of cultural heritage management. Among them and very important in the particularly context of the present study is the International Cultural Tourism Charter 
(ICOMOS, 1999). It is also important to highlight the Convention For The Safeguarding Of The Intangible Cultural Heritage by UNESCO (2003), because of its importance in formally recognize the needs to include the intangible cultural heritage into the scope of cultural heritage management. Finally, an earlier ICOMOS charters (ICOMOS, 2008) stress the importance of public communication as an essential part of the larger conservation process (variously describing it as "dissemination", "popularization", "presentation" and "interpretation"). According with this document "every act of heritage conservation is by its nature a communicative act" (ICOMOS, 2008).

The overall objective of these documents is to internationally outline the procedure for the conservation and enhancement of cultural heritage in its most varied manifestations. And this occurs for both the tangible and intangible heritage on varying scale and with varying complexity, but generally within a five-phase framework:
1. Inventory;

2. Legislated protection;

3. Asset management professionalization;

4. Stakeholders identification and consultation and

5. Situation review (McKercher \& du Cross, 2002).

In closing this in-depth review on the development of the concept of cultural heritage management, we can say that the internationalization of the responsibility for the protection of cultural resources, as well as the responsibility to seek together the guidelines for its management, were the great occurrence in this context, after the First and specially Second World War. This paradigm has definitely benefited the cultural heritage and the model of its management, both from theoretical and practical point of view. However, the major obstacle for the effectiveness of this paradigm characterized by the internationalization was always represented by the distance of the supranational institutions from the national and local reality, where the supranational guidelines

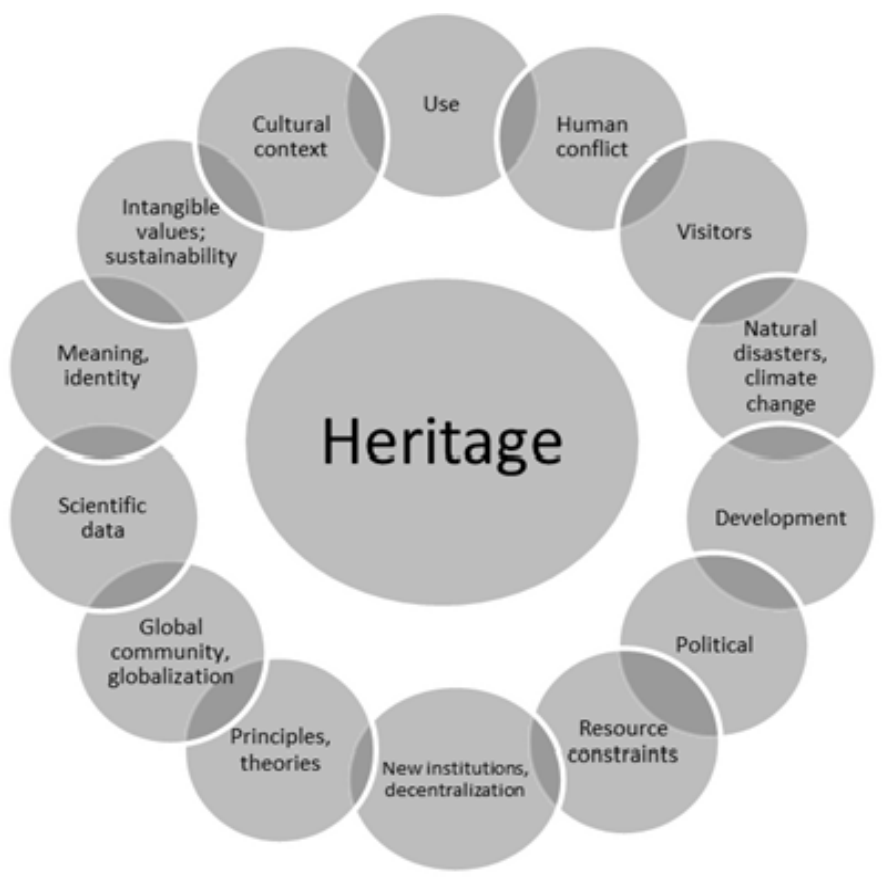

Figure 2. Multiple aspects associated to heritage and its management, nowadays Source: Adapted from UNESCO, ICCROM, ICOMOS, and IUCN (2013) 
(and good intentions) are entrusted to the local goodwill, level of awareness or capacity of interpretation. The question, at this point, is: would it be possible to create, disseminate and implement standards of quality management of cultural heritage? The answer to this question represent one of our theoretical contribution, and we will present this in the next section.

\section{Cultural Heritage Management today}

Nowadays is usual to find terms such as cultural and intercultural management or intercultural dialogue. We can consider these concepts as the evolution of what we analysed in the previous section. Today academics - as well as diplomats and international relations specialists - talk also about the use of culture within international relations, as alternative to the more coercive measures of persuasion in the international sphere (cultural diplomacy). Therefore, culture (and with it, its management and its use) is no longer just a set of values but becomes a factual "tool", a "power", the socalled soft power (Mazzei, 2012). Finally, as Babić (2015) has noticed, critical heritage studies over the last few years significantly influenced the perception of heritage and the essence of heritage management and stressing on participative approach in this context became fundamental.

There are indeed several socio-economic aspects that, nowadays, one can recognize as linked with cultural heritage and its management, as shown in the following figure.

Heritage managers in an integrated manner need to be able to consider all aspects related to heritage. Their task, today, is to identify and act on strategic opportunities to develop the sites with high level of quality (Drummond \& Yeoman, 2001; Leask \& Yeoman, 1999) and to work in partnership with key local and regional stakeholders (Pedersen, 2002: 24), since a general consensus has grown up on the fact that the protection and valorisation of cultural heritage can be a strategic driver for local development (Amendola \& Papaccio, 2014: 21).

Nonetheless, it seems that organizations that deal with the management of archaeological and, in general, cultural heritage show the same phenomena that Drucker (2001) described for non-profits organizations: he affirms that "they were proud in being freed from the taints of commercialism and be above such sordid factors such as financial results, and for this reasons they rejected the concept of management (...) as closely associated to profit sector" ( Drucker, 2001: 40-41). This phenomenon has similarities with some public institutions responsible for heritage management, who reject the traditional concept of management in the field of cultural heritage. Drucker concludes his reflexion about nonprofits organization by stating that they finally understood that "they need management even more than the business sector, precisely because they do not have the discipline of financial results: they understood that good intentions are not a substitute for organization, leadership, responsibility, performances and results. All this factors requires management, which - in turn - starts with the mission, which allows organizations focus on action, defining specific strategies to achieve the crucial goals. It creates a disciplined organization, and it prevents, by itself, most degenerative disease for organizations: the fragmentation of its resources, always limited in things that are interesting and that seem profitable instead of focusing on a small number of productive efforts" (Drucker, 2001: 41).

Quagliuolo (1998: 18-19) affirms that should exist a culture of quality in heritage management, intended as a tendency to ongoing improvement and a constant attention to the needs of the users of heritage attractions, whether tourists or residents. Oakland and Sohal (1996: 3) state that whatever type of organisation one works in, competition is rife, and, generally speaking, quality is the most important competitive weapons. In the specific case of cultural heritage management and its tourist enhancement, Conti (1998) adds that the approach of Total Quality Management would bring many benefits and improvements in the results of the efforts of the organizations in charge.

\section{Cultural Heritage Management and Quality}

We closed the third section with a question: how to define the action to overcome the weakness of the supranational organizations, 
namely the incapacity of their guidelines to take effect at the local level? It would be possible to create, disseminate and implement internationally to every monument and site open to the public of the standards of quality of the management of assets to reflect the guidelines of supranational organizations? The solution may lie in the formulation of a system of certification of quality inspired by the supranational guidelines and recognized globally, so that each monument and the area open to the public would follow the same standards (even if adaptable to the different realities) to reach quality in management.

The term management is more and more often accompanied by the word quality. If it is true for industry and services' sector, in general - as was presented in the previous section - in regards to the management of the heritage, some scholars and consultants talk about the cultural exception (HERITY, 2007: 9) and the last two decades has seen the birth of the first serious approaches through the prism of the most recent trends and philosophies about quality. A great impulse was given by the European Commission, which has invested significantly in preparation of recommendations for local stakeholders and has already made great efforts to raise awareness and promote a culture of quality: the Integrated quality management (IQM) of urban tourist destinations(European-Commission, 2000) is one of the publications that aims to reach this goal, in order to achieve the general objectives of the European Union, namely the promotion of the European citizen's interests, growth and employment, regional development, the management of cultural and natural heritage as well as the reinforcement of a European identity. Although this publication contains "only" recommendations and suggestions for stakeholders, the formula "integrated quality management" (European Commission, 2000: 21 ) began to appear, and marks one of the milestones for the growth of the debate.

Quality Management in Archaeology and Cultural Heritage deals with the effects of the profound changes that have had an impact on the discipline of archaeology all over the world (Willems, 2007) and the intensification of the debate on this issue - on the managerial and academic level - is demonstrated by the growing number of academic works such as Go and Govers (2000), as well as Timothy (2011) and Timothy and Boyd (2003) which explore these issues surrounding the management of cultural resources for tourism, looking at the social, physical and economic impacts, which cause destinations, site managers and interpreters to consider not only how to plan and manage resources but also how to portray the past in ways that are acceptable, accurate, accessible and politically relevant. The debate is also highlighted in annual international meetings, most of them focusing on heritage politics, heritage tourism, the authenticity and inauthenticity of place and experience, and the urgent need to protect living and built cultures, like the Mediterranean Archaeological Tourism Exposition at Paestum (Salerno, Italy); the WTE - Word tourism Expo, that focuses on heritage management and its tourist enhancement in the places that are part of the UNESCO World Heritage List; and other that focus more on the management and conservation, like "The Best in Heritage", launched in 2003 by the European Heritage Association (Zagreb, Croatia) that is an annual presentation of awarded museum, heritage, and conservation projects and institutions (at national and international level), where managers share valuable information outlining best practices in asset management; and the HERITY International Congress, that will be analysed hereafter. In this sense, authors like Manacorda (2007: 90) points out the necessity of sharing internationally, standards and methods of interdisciplinary intervention and management.

The perspective of Total Quality Management applied to Cultural Heritage Management

Organizational models of quality to help managers to identify and manage all the variables that are important to meet the expectations of all customers (internal and external) were born in the 1980's. TQM models are those that address more comprehensively, the issue of the adequacy of an organization for its own purposes (HERITY, 2007). The literature review has shown that the field of quality management applied to heritage tourism and cultural heritage is not particularly developed. As seen in previous sessions, the 
most recent theories on quality management point to a primacy of TQM philosophy (Conti, 1998). Therefore, search for data (both sectorial and scientific) related to the application of this concept to the management of cultural heritage for tourism purposes seems appropriate.

Conti (1998: 30) explains that the concept of TQM is characterized by the shift of emphasis from the quality of products and services, to the quality of the organizations that produce these products and services. This different paradigm related to quality management can represent the point of convergence between heritage management and quality. Still, Conti (1998: 30) shows that the implementation of quality management through TQM leads to an increased focus on leadership, culture and values of the organization; continuous improvement, involving the area of human resources and influencing processes, being applicable to all types of organized human activity, both in the sphere of profit as in the non-profit. At this point, Marnetto (2009: 54) affirms that the cultural asset must be seen as an organism and not just as a place, so the TQM philosophy becomes fully applicable to cultural heritage management.

At the same time, even supranational entities recognize, due the dramatic expansion of interpretive activities and the introduction of elaborate interpretive technologies and new economic strategies for the marketing and management of cultural heritage sites, the need for basic principles of management, namely for the Interpretation and Presentation as essential components of heritage conservation efforts and as a means of enhancing public appreciation and understanding of cultural heritage sites (ICOMOS, 2008). In recognizing that interpretation and presentation are part of the overall process of cultural heritage conservation and management (ICOMOS, 2008) seeks to establish seven cardinal principles, upon which Interpretation and Presentation should be based:

- Principle 1: Access and Understanding

- Principle 2: Information Sources

- Principle 3: Attention to Setting and Context

- Principle 4: Preservation of Authenticity
- Principle 5: Planning for Sustainability

- Principle 6: Concern for Inclusiveness

- Principle 7: Importance of Research, Training, and Evaluation

Once the consensus existing around the necessity of creating well-defined and internationally agreed principles for heritage management, and the opinion that the application of quality systems could have a decisive importance in this field was demonstrated, one can report the pertinent reflection of Natali (2005: 30) about the importance of quality and its certification. The author states that the demand for quality is an imperative and a differentiating factor in every sector of society to face an increasingly exasperated competitiveness, and in this context the implementation of quality certification represent a useful tool for users and consumers in order to extricate itself from the many "quality proposals" (Natali, 2005).

Between the different costs and effort associated with the implementation of a system of quality management in an organization, as listed by Pinto and Soares (2009: 26), there is the time spent in assisting the various activities and preparation of necessary documentation. Although there is a growing sensitivity on the part of the profit organizations to consider such efforts as an investment, and not a cost (Calderón Perez \& Casas Novas, 2009; Pinto \& Soares, 2009), most of heritage managers still believe this effort is excessive and almost useless. On the contrary, if one recognizes quality systems as a useful frameworks in the management of assets - and taking into account that, as Natali (2005: 30) highlights, quality is also increasingly associated with the concept of sustainability, being considered the key to the sustainable development strategies - as a corollary of this proposition the certification becomes an additional added value for both the users and heritage managers. For this reason, the next session will be dedicated to the quality certification system applied to cultural heritage management.

\section{Awards and certifications}

The need to recognize, in the context of "organizations" that operate in the heritage those who strive to achieve excellent levels of 
their performances and the quality of their results, gave birth to several official international recognition and awards. The Best in Heritage, for example, launched in 2003 by the European Heritage Association (Zagreb, Croatia) is an annual presentation of awarded (at national or international level) museum, heritage, and conservation projects and institutions. Directors and managers of the awarded sites explain why their institution/project was declared the best in the previous year, receiving a prize or award. Organizers will just let them present themselves and will neither evaluate nor give awards: the aim is to present quality projects sharing best practices at international level. We can define it as an event that tends to encourage, through the exchange of good practice, other heritage managers. Though we cannot find in this recognition a clear definition of quality standards for the management of cultural heritage. The positive contribution of this award is limited to the promotion of best practices, without any in-depth management models analyses.

Another award at European level is the European Museum of the Year Award (EMYA). It is annually organised by The European Museum Forum (EMF), European non-profit organisation that operates under the auspices of the Council of Europe and is involved in arranging activities throughout the cultural field. The EMYA was created in 1977 with the main purpose of "recognising excellence in the European museum scene and encouraging innovative processes in a museum world which still took the more traditional view to focus exclusively on collections rather than on their use for the benefit of society" (search: http://www.europeanmuseumforum.info/). A further recognition of the excellence displayed by the winning museums in the approach they take to museum work, while complying fully with the EMYA criteria, is the Council of Europe Museum Prize. It is a unique award intended to highlight the need to preserve and promote the European cultural heritage as a factor uniting the Council of Europe's member states. Through an analyses of this award we find out that its approach (with the existence of criteria previously defined by EMYA) is far more effective than previous awards described, in terms of clear definition of quality standards for cultural heritage. Nevertheless, these standards are not globally recognized, so that finally this recognition joins the fairly large number of awards for "excellence", "innovation" and a not well defined "quality" within the field of cultural heritage. A more systematic and effective approach was given in this sense by HERITY, an international organization, which has created a quality assessment framework for the management of cultural heritage, through the study, revision and application of previous excellence and quality models from other areas, such as those shown in the previous section. This model has been the basis for the establishment of criteria that evaluated the quality of management, certifying it. This system is commonly known by the name of HERITY Global Evaluation System.

\section{HERITY Global Evaluation System (HGES)}

After analysing some of the most important awards and certifications within the cultural heritage - avoiding enumerating the countless systems adopted just at local or regional level in this section we focus on what is the only worldwide certification also recognized by UNESCO. As Pinto and Soares (2009) highlight, Quality is the result of an organizational compromise between culture, politics of quality, and the use of certain resources and appropriate frameworks (ensuring excellent performance and their continuous improvement) which must also be recognized. As the same authors stand, the certification should not be the only objective of implementing the quality system, however, it is the unequivocal evidence, among employees, customers, and other interested parties of the efforts made by the organization at the level of quality (Pinto \& Soares, 2009: 32). It becomes an integral part of the application of these concepts in the management of cultural heritage.

Regarding the Cultural Heritage Quality Management, as pointed out by Natali (2005: 31 ) the affluence of visitors often represent a quantitative data used as an indicator of quality of a site or museum, even if it can actually bring misleading information to managers and even to the public. In this context, the HGES represents a valid methodological proposal for 
the assessment of cultural heritage management (Natali, 2005: 30). Operational relevance, scientific basis and credibility" are the characteristics evidenced by UNESCO to describe the results of the HERITY certification system, as reported by Marnetto (2009: 52). HGES is a tool that allows a periodic assessment of cultural sites, including those entered in the UNESCO List of World Heritage Sites, and should be used as a support tool for heritage managers and as platform for dialogue with the tourism industry as well as operators of regional planning (Natali, 2005: 31).

\section{HGES: Background}

HERITY - International Organization for Quality Management of Cultural Heritage was launched in Italy in 1994, by the DRI Interregional Agency for Cultural Programming and Tourism, as an international forum with the main objective to create an effective proposal for the management of cultural resources.

HERITY has been testing its principles up until 1998 when they were adopted. Only after some years, in 2002, it was decided to codify this know-how by setting criteria, parameters prerequisites and indicators in order to be able to evaluate the quality level reached at the cultural heritage places open to the public (museums, monuments, churches, castles, palaces, villas, parks, archaeological sites, etc.). Quagliuolo (2001) has explained that the certification is based on an assessment of the sites management with regards to the degree of the dimensions exposed in the following table:

The main set of questions and problems to be answered came from the observation of visitor behaviour in Rome, as an example of Art City characterized by cultural vestiges and activities as well by significant tourism pressure. From a technical point of view, the HGES was specifically designed for Cultural Heritage and brings together the logic of various quality and certification systems, such as ISO, TQM systems, or, again, the classification systems of Michelin (Natali, 2005: 32). Today, HERITY is presented in different countries, like Italy, Spain, Brazil, Portugal, Sweden, United Kingdom, Lithuania, Czech Republic, France, Turkey, among others.

\section{HGES: Assessment}

HERITY was specifically designed to measure the performance achieved in the management of cultural heritage (Natali, 2005: 32). HGES can be characterized as:

1) Multi-dimensional, as it analyses and describes four different dimensions of cultural heritage;

2) Multi-purpose, since it is directed to the needs of the public as well as operators and stakeholders;

3) Multi-perspective, reaching its results thanks to the contribution of different sources: selfassessment of responsibility, an external evaluation and the opinion of the public.

The specific objective of HGES is assessing the cultural asset based on 4 different criteria (perceived value, conservation, communication capacity, services), which refer to 182 requirements, divided into 16 areas (parameters) (Quagliuolo, 2001: 251). Principles, criteria, sub-criteria, indicators and requirements of the HGES are the result of nine years of meetings of experts from the cultural sector, communication, organization, Total Quality Management, law and economics; both from private sector as well as 15 countries institutional (Natali, 2005). During the assessment period, four different points of view are considered for the evaluation:

Table 1. Dimensions considered and examined by HGES

\begin{tabular}{ll}
\hline Dimension & Definition \\
\hline Perceived Value & $\begin{array}{l}\text { Tangible and intangible relevance commonly attributed to a good, } \\
\text { regardless of the reason. }\end{array}$ \\
Preservation Capability & $\begin{array}{l}\text { Procedure to establish the conditions for the creation, maintenance and/or } \\
\text { growth of perceived value over time. }\end{array}$ \\
Transmitted Information & $\begin{array}{l}\text { Set of actions implemented for the dissemination of the knowledge about } \\
\text { the perceived value. } \\
\text { Direct or indirect activities aimed to the appreciation in optimal conditions of } \\
\text { the perceived value of an asset. }\end{array}$ \\
\hline
\end{tabular}


1. Managers of the site;

2. HERITY specialists;

3. Visitors;

4. Stakeholders.

The layout of the process is:

1. A "visual synthesis" of results (the HERITY Target);

2. A the introduction of a control system that can be easily managed by operators;

3. A detailed report of the evaluation to the managers.

The HERITY Target which is normally affixed to the entrance of the certificated site and illustrate the result of the evaluation on a scale from one to five, combining the opinions of the managers, specialist and public. The following Figure 4 is a concrete example of the output of the system (together with the final report), representing the result of the assessment process of the Museu de Arte Pré-Histórica e do Sagrado no Vale do Tejo (Mação, Portugal), dedicated to the spiritual and symbolic manifestations of the sacred, from the prehistoric fertility rituals to worship the dead megalithic, passing through the medieval sacred art.

The four quadrants of the HERITY Target provide to the public the information presented in Table 2.

On the other hand, the report elaborated by HERITY at the end of each assessment, becomes an effective instrument for heritage managers in order to measure the success of management plans and detect areas in which it is necessary to intensify efforts (Natali, 2005: 32). In other words, it is possible to say that HERITY is an intermediate instrument, and provide the following services:

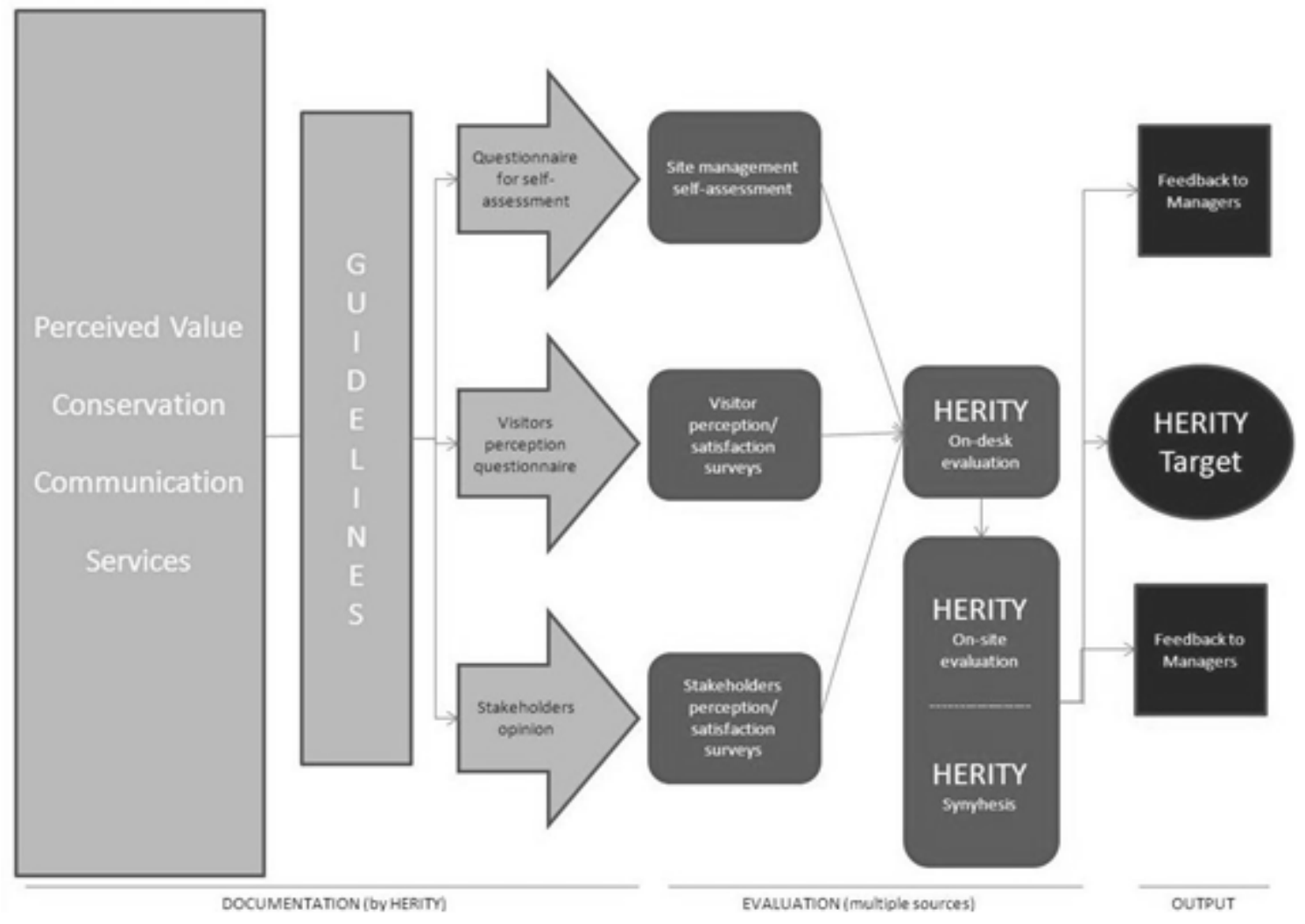

Figure 3. The HGES Assessment Process Source: Adapted from HERITY (2009) 
1. Helps public to decide;

2. Encourage managers to improve standards

3. Provide guarantees to institutions on respect minimum levels (Quagliuolo, 2001).

HERITY attributes its appreciation for a period of three years. A system for monitoring and reevaluation at the end of three years period verifies the level reached and adjusts the assessment.

\section{Conclusion}

With this theoretical overview over the topic of Cultural Heritage Quality Management, we aim to highlights some specific aspects in order to provide a theoretical basis for future empirical studies. Nevertheless, the theoretical work here presented here already allows us to draw some important conclusions. We can firstly affirm the strategic importance of the awareness related to the conceptual difference existing between cultural resource and cultural tourist attraction. In particular, on the side of policy maker and operators, the perception regarding this differentiation should be considered as a benefit towards the success of the management policy they develop.

On the other hand, after the analysis of the evolution of guidelines defined by supranational

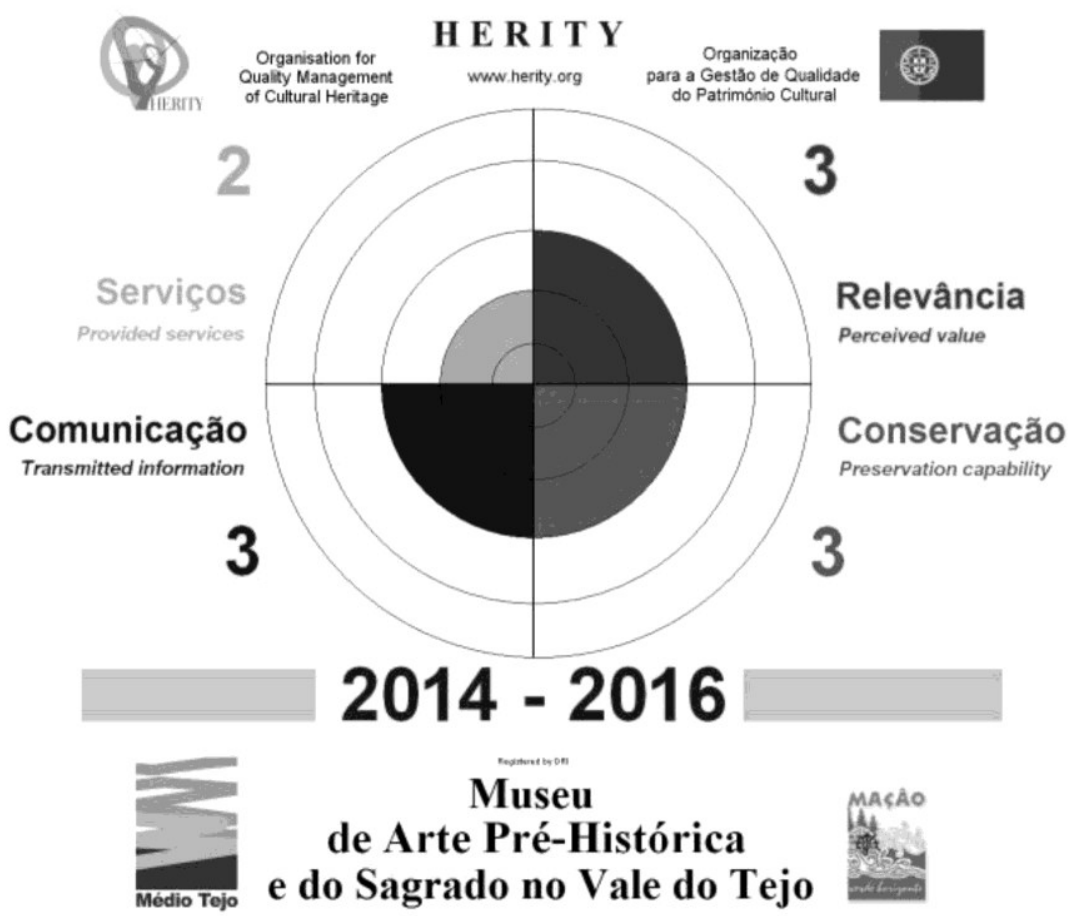

Figure 4. The HERITY Target at the Museu de Arte Pré-Histórica e do Sagrado no Vale do Tejo (Mação, Portugal).

Source: Image courtesy of HERITY

Table 2. Information provided by the HERITY Target

\begin{tabular}{ll}
\hline Quadrant (Dimension) & Provided information \\
\hline Perceived Value & Importance of the heritage place. \\
Preservation Capability & State of maintenance, preservation and restoration. \\
Transmitted Information & $\begin{array}{l}\text { Information provided to the visitor, thus, possibility to understand the } \\
\text { message and interpret the heritage place. }\end{array}$ \\
Provided Services & $\begin{array}{l}\text { Quality of reception and services offered. Opportunity to better appreciate } \\
\text { the visit thanks to its facilities. }\end{array}$ \\
\hline
\end{tabular}


bodies about the cultural heritage management, we consider wondering about the effectiveness of the "internationalisation" of the responsibility of cultural heritage protection and management as an important issue. The weakness found is that of the impossibility of being able to effectively ensure the implementtation of the supranational guidelines at the local level. Therefore, a tool to provide a bridge between the supranational and the local level until the single monument or heritage place would be necessary. These considerations leads us to a further conclusion: the instrument that conceptually fill this "gap" could be represented by the presence of globally accepted dimensions of Quality within Cultural Heritage Management, inspired by the supranational directives. The creation of such dimensions and standards and its concrete use would guarantee, ideally, the compliance by each museum, monument and cultural heritage area open to the public with the orientations defined at supranational level. Quality would have, in this context, the main pursuit of disseminating and ensuring the implementation of the guidelines that bodies such as UNESCO and the UNWTO, among others, recommend. We consider this one of the main points of convergence between Cultural Heritage Management and Quality.

In particular, it is worth to notice that this convergence becomes effective only since the principles of quality and the cultural heritage management follow the TQM philosophy. In fact, by analogy, as the quality in the industrial sector was related purely to the control of conformity of the final products, in the same way in cultural heritage management, methodologies such as the visitors' satisfaction survey are no longer enough to define the level of quality of a cultural place and that of the tourism experience. With the new approach of $T Q M$, the focus is no longer merely on the final product (that is, in our case, the satisfaction of the visitors), but on the organization's culture and values, processes, ethics and continuous efforts for improvement towards excellence. Thus, at this point, the evolution of the concept of quality met the evolution of the paradigms of heritage management.
We have also saw (section 7) that the need for internationally accepted dimension of quality within cultural heritage management and the application of the TQM principles are satisfied through the concept underlying the HERITY Global Evaluation System. The latter is, thus, the only assessment system in the cultural heritage management, up to the date, that meet the needs to fulfil the existing gap existing between the elaboration of supranational guidelines and their effective implementation. HERITY is recognized for its Global Evaluation System that has four main dimensions of quality within cultural heritage management. According to what exposed above, thus we conclude that the dimensions considered by HERITY actually represent an important and operational synthesis of the concepts, methodologies and guidelines related with an optimal cultural heritage management process.

However, a broader consideration leads us to further conclusions. The post-capitalist society in which we live considers the knowledge as one of the most important resources for development and, on the other hand, local identity and cultural diversities - thus, the selfknowledge - are often evoked as positive factors in times of globalization. Therefore, we conclude that there is a need of policies enhancing cultural heritage towards this contemporary challenge and, in particular, valuing the cultural heritage in order to enhance local identities and, on the other hand, tourism activity as a way of intercultural dialogue and mutual understanding represents an important part of this challenge. Back to the matter of cultural heritage quality management, we consider then that this concept should take into account the role of cultural heritage within a society of knowledge and self-knowledge. In particular, we conclude that the existence of further dimensions of a cultural heritage quality management, such as the capacity of involvement of local population (actually existing in the current evaluation system, but little asserted) and the ability to promote intercultural dialogue based on cultural heritage enhancement and tourism activity, would be recommendable.

An approach consistent with the relentless "paradigm of complexity" requires us to look at the cultural heritage and its management within 
the context of regional development (socioeconomic and cultural) through tourism, as an integrated and holistic matter. Therefore, we have to ensure that the idea of quality in the field of cultural heritage management takes into account this complexity, which means ensuring a highly positive and sustainable contribution in the context of radical socio-economic changes of our time.

\section{References}

Alegre, J., \& Garau, J. (2010). Tourist Satisfaction and Dissatisfaction. Annals of Tourism Research, 37(1), 52-73.

Amendola, A., \& Papaccio, A. (2014). Driving local development via cultural networking. In L. Oosterbeek \& F. Pollice (Eds.), Cultural Heritage and Local Development. Local communities through heritage awarness and global understanding. (pp. 20-39). Ravello: Centro Universitario Europeo per i Beni Culturali.

Archer, C. (2001). International Organizations: Routledge.

Babić, D. (2015). Social Responsible Heritage Management - Empowering Citizens to Act as Heritage Managers. Procedia Social and Behavioral Sciences, 188, $27-$ 34.

Bell, P. M. H. (2007). The Origins of the Second World War in Europe: Pearson Education Limited.

Boniface, P. (1995). Managing Quality Cultural Tourism. London, UK.: Routledge.

Bounfour, A., \& Edvinsson, L. (2005). Intellectual Capital for Communities. Nations, Regions and Cities (A. Bounfour \& L. Edvinsson Eds.). USA: Elsevier Butterworth-Heinemann.

Bowitz, E., \& Ibenholt, K. (2009). Economic impacts of cultural heritage e Research and perspectives. Journal of Cultural Heritage, 10, 1-8.

Calderón Perez, E., \& Casas Novas, L. (2009). Costes de calidad y de no calidad: delimitacion de conceptos y reflexiones en cuanto al papel de la contabilidad de gestión. In M. Saraiva \& A. Teixera (Eds.), A Qualidade numa Perspectiva Multi e Interdisciplinar (pp. 148-167). Lisbon: Silabo Edições.
Carbone, F., Oosterbeek, L., \& Costa, C. (2012). Paideia approach: bridging tourism and community development on the basis of heritage enhancement. Revista Turismo e Desenvolvimento Journal of Tourism and Development, 17/18, 165-166.

Carbone, F., Oosterbeek, L., \& Costa, C. (2013). Paideia approach for heritage management.The tourist enhancement of archaeologicalheritage on behalf of local communities. PASOS. Revista de Turismo y Patrimonio Cultural, 11(2), 285-296.

Colombo, E. (2011). Le Societá Multiculturali (2nd ed.). Roma: Carocci.

Conti, T. (1998). Turismo e beni culturali nella prospettiva del Total Quality Management (TQM). Paper presented at the 3rd International Meeting on Cultural Heritage Management, "Turismo e Beni Culturali e Ambientali", Cagliari (Italy).

Cooper, C., Fletcher, J., Gilbert, D., Sheperd, R., \& Wanhill, S. (1998). Tourism: Principles and Practice. London, UK: Longman.

D'Amore, L. (1988). Tourism - The World's Peace Industry. Journal of Travel Research, XXVII(1), 35-40.

Dallen, T. J. (1996). Tourism and the Personal Heritage Experience, . Research Notes and Reports, 751-754.

de Rojas, C., \& Camarero, C. (2008). Visitors' experience, mood and satisfaction in a heritage context: Evidence from an interpretation center. Tourism Management, 29(3), 525-537.

Drucker, P. (2015). Sociedade Pós-Capitalista (2nd ed.). Lisboa: Actual Editora.

Drucker, P. F. (2001). The Essential Drucker. New York: HarperCollins.

Drummond, S., \& Yeoman, I. (2001). Quality Issues in Heritage Visitor Attractions. Oxford: Butterworth-Heinemann.

Ekinci, Y., \& Hosany, S. (2006). Destination Personality: An Application of Brand Personality to Tourism Destinations. Journal of Travel Research, 45, 127-139.

European Commission (2000). Towards Quality Urban Tourism. Integrated quality management (IQM) of urban tourist destinations. Italy: European Communities. 
Gienow-Hecht, J. C. E., \& Donfried, M. C. (2010). Searching for a Cultural Diplomacy. USA: Berghahn Books.

Go, F. M., \& Govers, R. (2000). Integrated quality management for tourist destinations: a European perspective on achieving competitiveness. Tourism Management, 21(1), 79-88.

Gunn, C. A. (1988). Vacationscape: Designing Tourist Regions (2nd ed.). New York: Van Nostrand Reinhold.

Gunn, C. A. (2002). Tourism Planning (4th ed.): Routledge.

HERITY (2007). Guida Alla Valutazione HERITY (Rev. 12/08/2007). HERITY. Roma (Italy).

HERITY (2009). HERITY Official Brochure. Rome: Enotria Onlus.

ICOMOS (1964). International Charter For The Conservation And Restoration Of Monuments And Sites. Venice.

ICOMOS (1999). International Cultural Tourism Charter. Managing Tourism at Places of Heritage Significance. Mexico.

ICOMOS (2008). Charter for the Interpretation and Presentation of Cultural Heritage Sites. Québec (Canada).

Kawamura, N. (2000). Turbulence in the Pacific: Japanese-U.S. Relations During World War I: Praeger.

Leask, A., \& Yeoman, I. (1999). Heritage Visitor Attractions: An Operations Management Perspective. UK: Cassell.

Leiper, N. (1990). Tourist attraction systems. Annals of Tourism Research, 17, 367384.

MacCannell, D. (1976). The Tourist: A New Theory of the Leisure Class. New York: Schocken Books.

Malek, A., \& Costa, C. (2014). Integrating Communities into Tourism Planning Through Social Innovation. Tourism Planning \& Development, 1-19. Retrieved from http://dx.doi.org/10.1080/ 21568316.2014.951125

Malek, A., \& Mohamed, B. (2014). Evaluation of urban tourism products: Kuala Lumpur as a destination of choice. Journal of Tourism \& Development, 3(21/22), 8393.

Manacorda, D. (2007). II sito archeologico: fra ricerca e valorizzazione. Roma: Carocci.
Marnetto, G. (2009). HERITY e I'UNESCO: riconoscere la qualitá del "valore eccezionale". SITI. Trimestrale di attualitá e politica culturale, 2, 52-55.

Mazzanti, M. (2003). Valuing cultural heritage in a multi-attribute framework microeconomic perspectives and policy implications. Journal of SocioEconomics, 32(5), 549-569.

Mazzei, F. (2012). Relazioni Internazionali. Milano: Egea.

McKercher, B., \& du Cross, H. (2002). Cultural tourism: the partnership between tourism and cultural heritage management. Binghamton, New York: The Haworth Hospitality Press.

Moraes, A. (2006). Competitividade e Sustentabilidade: é possível as cidades turísticas serem sustentáveis e competitivas ao mesmo tempo? Pasos Journal of Tourism and Cultural Heritage, 4, 443-446.

Natali, F. (2005). Una certificazione di qualitá per i siti UNESCO. SITI. Trimestrale di attualitá e politica culturale, 1, 30-33.

Oakland, J. S., \& Sohal, A. S. (1996). Total Quality Management. Text with cases. Oxford: Butterworth Heinemann.

Oosterbeek, L. (2015). Revisitando Antígona: O Património Cultural Na Fronteira Da Globalização. In Juliano Bitencourt Campos, Daniel Ribeiro Preve, \& I. F. d. Souza (Eds.), Patrimônio cultural, direito e meio ambiente. Um debate sobre a globalização, cidadania

sustentabilidade (Vol. 1). Curitiba: Multideia.

Oosterbeek, L., \& Pollice, F. (2014). Cultural Heritage and Local Development. Local communities through heritage awarness and global understanding. Territori della Cultura(18).

Pearce, P. (1991). Analysing tourist attractions. Journal of Tourism Studies, 2(1), 46-55.

Pedersen, A. (2002). Managing Tourism at World Heritage Sites: a Practical Manual for World Heritage Site Managers. France: UNESCO World Heritage Centre.

Pinto, A., \& Soares, I. (2009). Sistemas de Gestão da Qualidade. Guia para a sua implementação. Portugal: Silabo. 
Quagliuolo, M. (1998). Prospettive di sviluppo Territoriale attraverso la valorizzazione dei beni culturali e la cultura dell'ospitalitá. Paper presented at the 3rd International Meeting on Cultural Heritage Management, "Turismo e Beni Culturali e Ambientali", Cagliari (Italy).

Quagliuolo, M. (2001). Qualitá nella gestione di un bene culturale: il riconoscimento HERITY. Paper presented at the 6th International Meeting on Cultural Heritage Management, "Qualitá e Beni Culturali e Ambientali", Barletta (Italy).

Richards, G., \& Munsters, W. (2010). Developments and Perspectives in Cultural Tourism Research. In G. R. a. W. Munsters (Ed.), Cultural Tourism Research Methods (pp. 1-12): CABI Publishing.

Spyriaris, T., Fletcher, J., \& Fyall, A. (2013). Destination Management Organisational Structures. In C. Costa, E. Panyik, \& D. Buhalis (Eds.), Trends in European Tourism Planning and Organisation (pp. 77-91). UK: Channel View.
Timothy, D. J. (2011). Cultural Heritage and tourism. An Introduction. UK: Channel View.

Timothy, D. J., \& Boyd, S. (2003). Heritage Tourism. UK: Prentice Hall.

Timothy, J. D., \& Saarinen, J. (2013). Crossborder Cooperation and Tourism in Europe. In Carlos Costa, Emese Panyik, \& D. Buhalis (Eds.), Trends in European Tourism Planning and Organisation (pp. 64-74). UK: Channel View.

UNESCO. (2000). Culture, Trade and Globalization - Questions and Answers. Paris: UNESCO Publishing.

UNESCO. (2003). Convention For The Safeguarding Of The Intangible Cultural Heritage. Paris.

Willems, W. (2007). Quality Management in Archaeology Oxbow Books. 